\title{
Larger forests into fewer hands: how equitable is Community forestry in Nepal?
}

\begin{abstract}
Anuja Raj Sharma ${ }^{1}$
This paper assesses the much talked equity aspect in community forestry. There is an increasing concern regarding the hand over of community forests without any threshold for per household forest area. Using Gini coefficient as a measure of inequality, this paper concludes that there is high inequality in the hand over of community forests to the beneficiary households.
\end{abstract}

Keywords: Gini coefficient, inequality, community forests, household

$\mathbf{M}$ uch has been written about the equity aspect of Community Forestry (CF). A compendium of research papers published by Winrock International-Nepal in 2002 includes many papers on this aspect. The main concern expressed in these papers is that community forests are being handed over in a haphazard way without any consideration on equity aspect. Larger tracts of forests (>100 ha) have been handed over to the Forest User Groups (FUGs) comprising fewer households while a large number of households are included in smaller patches of community forests (<100 ha). This has led into a situation where material benefits are not accruing sufficiently to a large number of forest user households while a few households are using forests indiscriminately.

It necessitates a serious empirical test on equity in community forestry. This paper aims to quantify the magnitude of inequality arising due to this discriminatory practice of hand over of community forests.

\section{Materials and method}

A tool called Gini concentration ratio or simply Gini coefficient is used to assess inequality. The tool is named after the Italian Statistician who first formulated it in 1912. The tool is an aggregate numerical measure of inequality ranging from 0 (perfect equality) to 1 (perfect inequality). The higher the value of the coefficient, the higher the inequality of distribution; or other way round. This tool is used to find out whether the distribution of community forests to the beneficiary households has remained equitable or as feared by many Scholars (Bhatta, 2002a,b; Tiwari, 2002 etc) that larger tracts of forests are handed over to small group of households while a large number of households are accommodated in smaller patches of forest from which the latter can get almost no material benefit.

For grouped data Gini coefficient is calculated by using the following formula (Kanel, 1993).

$\mathrm{G}=\sum \mathrm{X}_{\mathrm{i}} \mathrm{Y}_{\mathrm{i}+1}-\sum \mathrm{X}_{\mathrm{i}+1} \mathrm{Y}_{\mathrm{i}}$

Where $\mathrm{X}_{\mathrm{i}}$ denotes the cumulative proportion of the population in the ith class interval, and

Yi denotes the cumulative proportion of the population in the ith class interval.

When the variables are measured as percentages, both of them have to be divided by 100. In this case the above equation has to be written as:

$\mathrm{G}=1 /(100)^{2}\left[\sum \mathrm{X}_{\mathrm{i}} \mathrm{Y}_{\mathrm{i}+1}-\sum \mathrm{X}_{\mathrm{i}+1} \mathrm{Y}_{\mathrm{i}}\right]$

\section{Results and discussion}

Figure 1 shows the distribution of community forests by cumulative percentages of households and forest area. It is the construction of a Lorenz curve for the distribution of community forests in Nepal and is based on the national FUG database. The further the curve from the diagonal line passing through the origin, the greater is the inequality in the distribution of community forests. The figure clearly shows that almost $70 \%$ of the households are accommodated within little more than $30 \%$ of the total community forest area while nearly $70 \%$ of the forest area is handed over to just about $30 \%$ of the forest user households. 


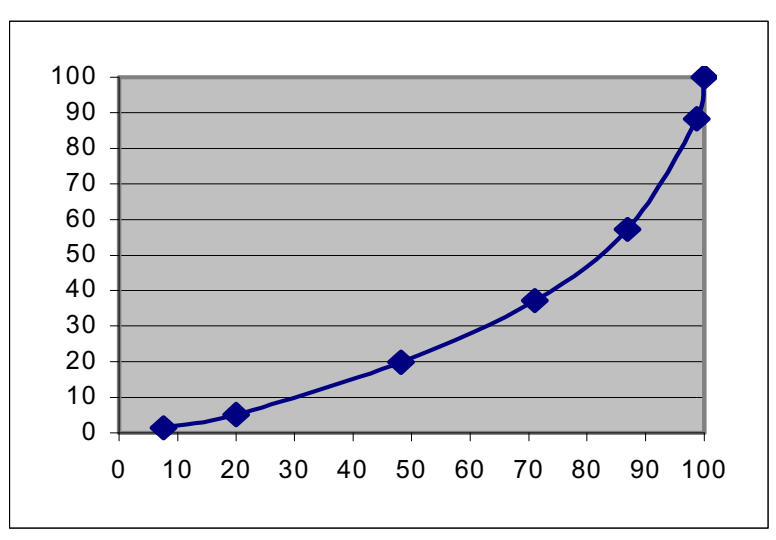

Figure 1: Distribution of community forests by cumulative percentage of households and forest area.

The distribution of community forests in Nepal by size of the forest is given in Table 1. Scrutinizing the table shows that $63 \%$ of the households have community forests less than 100 hectares and it constitutes only $29 \%$ of the total area of the community forest. The remaining $37 \%$ of the households have community forests larger than 100 hectares and such forests constitute $71 \%$ of the total area of the community forest. This suggests high inequality in the handing over of community forests to the local FUGs and consequently the Gini coefficient is 0.445 . The detail of the calculation of Gini coefficient is given in the Annex 1. The larger-sized community forests are in the hand of fewer households in comparison to smaller-sized community forests in which a larger number of households are accommodated in the FUGs.

The basic statistics of community forestry in Nepal by size of the forest is given in Table 2. From Table 2 , we can see that per household community forest area ranges from 0.08 to 3.96 ha depending on the smallest and largest forest tracts. The table again justifies the claim that community forests are handed over on demand basis rather than any consideration of supply side.

\section{Conclusion}

The calculated Gini coefficient shows high inequality in the distribution of community forests. The distribution has remained largely inequitable. The larger tracts of the community forests have been handed over to the FUGs comprising fewer households while a large number of households have been included in the smaller community forests. Hence, it is strongly recommended that the concerned

Table 1: Gini coefficient of community forest distribution by size of the forest in Nepal, 2004.

\begin{tabular}{|c|c|c|c|c|c|}
\hline Community forest (1) & No of FUGs (2) & $\begin{array}{l}\text { Total CF in ha } \\
\text { (3) }\end{array}$ & $\begin{array}{c}\text { Total \# of HH } \\
\text { (4) }\end{array}$ & $\begin{array}{c}\text { Total area } \% \\
\text { (5) }\end{array}$ & $\begin{array}{c}\text { Total HH \% } \\
(6)\end{array}$ \\
\hline less than 10 ha & 2736 & $13,932.70$ & 185,261 & 1.2 & 11.8 \\
\hline 10 to $50 \mathrm{ha}$ & 5227 & $135,069.23$ & 489,733 & 11.9 & 31.1 \\
\hline 50 to 100 ha & 2553 & $179,912.03$ & 314,356 & 15.8 & 20.0 \\
\hline 100 to $200 \mathrm{ha}$ & 1882 & $260,911.95$ & 272,579 & 22.9 & 17.3 \\
\hline 200 to 500 ha & 1099 & $321,340.64$ & 233,304 & 28.2 & 14.8 \\
\hline 500 to 1000 ha & 210 & $141,362.74$ & 58,195 & 12.4 & 3.7 \\
\hline more than 1000 ha & 51 & $86,683.71$ & 21,883 & 7.6 & 1.4 \\
\hline Total & 13758 & 1139213 & 1304614 & 100.0 & 100.0 \\
\hline Gini coefficient & & & & & 0.445 \\
\hline
\end{tabular}

Source: Author's computation from National FUG database, DoF, 2004.

Table 2: Statistics related with community forests in Nepal.

\begin{tabular}{lccc}
\hline \multicolumn{1}{c}{ Community forest group (1) } & $\begin{array}{c}\text { Average CF } \\
\text { in ha. (2)* }\end{array}$ & $\begin{array}{c}\text { \# HH in FUG } \\
(3)^{* *}\end{array}$ & $\begin{array}{c}\text { Per HH Forest } \\
\text { in ha. (4)*** }\end{array}$ \\
\hline less than $10 \mathrm{ha}$ & 5.09 & 67.71 & 0.08 \\
10 to $50 \mathrm{ha}$ & 25.84 & 93.69 & 0.28 \\
50 to $100 \mathrm{ha}$ & 70.47 & 123.13 & 0.57 \\
100 to $200 \mathrm{ha}$ & 138.64 & 144.83 & 0.96 \\
200 to $500 \mathrm{ha}$ & 292.39 & 212.29 & 1.38 \\
500 to $1000 \mathrm{ha}$ & 673.16 & 277.12 & 2.43 \\
more than $1000 \mathrm{ha}$ & 1699.68 & 429.08 & 3.96 \\
\hline
\end{tabular}

Obtained from Table 1 dividing

* Column 3 by column 2

** Column 4 by column 2

*** obtained by dividing column 2 of table 2 by column 3 of the same table. 
authority should initiate the practice of calculating Gini coefficient of community forest distribution in Nepal and compare whether community forests are becoming more inequitable.

\section{Acknowledgement}

This paper is based on an ongoing research entitled "The Impact of Community Forestry on Income distribution in Nepal". The author thanks Winrock International- Nepal for the research grant.

\section{References}

Bhatta, B. 2002a. Access and Equity Issues in High Mountain Region Implications of Community Forestry Programme. In Policy analysis of Nepal's Community Forestry Programme A Compendium of Research Papers. Winrock International-Nepal. Policy Analysis in Agriculture and Related Resource Management (PAARRM) Programme.
Bhatta, B. 2002b. Access and Equity Issues in Terai Community Forestry Programme. In Policy analysis of Nepal's Community Forestry Programme A Compendium of Research Papers. Winrock International-Nepal. Policy Analysis in Agriculture and Related Resource Management (PAARRM) Programme.

Kanel, N. R. 1993. "Lorenz Curve and Gini Coefficient: Conceptual Considerations," The Economic Journal of Nepal, Vol. 16(4) (OctoberDecember), Central Department of Economics, T.U.

Tiwari, S. 2002. Access, Exclusion and Equity Issues in Community Management of Forests An analysis of status of Community Forestry in the Mid-hills of Nepal. In Policy analysis of Nepal's Community Forestry Programme A Compendium of Research Papers. Winrock International-Nepal. Policy Analysis in Agriculture and Related Resource Management (PAARRM) Programme.

Annex 1: Calculation of Gini coefficient of CF distribution by size of the forest.

\begin{tabular}{|c|c|c|c|c|c|}
\hline Size of CF & & No of forest & Total area (ha) & \multicolumn{2}{|c|}{ Total \# of $\mathrm{HH}$} \\
\hline less than 10 ha & & 2736 & $13,932.70$ & \multicolumn{2}{|c|}{$185,261.00$} \\
\hline 10 to $50 \mathrm{ha}$ & & 5227 & $135,069.23$ & \multicolumn{2}{|c|}{$489,733.00$} \\
\hline 50 to 100 ha & & 2553 & $179,912.03$ & \multicolumn{2}{|c|}{$314,356.00$} \\
\hline 100 to $200 \mathrm{ha}$ & & 1882 & $260,911.95$ & \multicolumn{2}{|c|}{$272,579.00$} \\
\hline 200 to 500 ha & & 1099 & $321,340.64$ & \multicolumn{2}{|c|}{$233,304.00$} \\
\hline 500 to 1000 ha & & 210 & $141,362.74$ & \multicolumn{2}{|c|}{$58,195.00$} \\
\hline more than 1000 ha & & 51 & $86,683.71$ & \multicolumn{2}{|c|}{$21,883.00$} \\
\hline Total & & 13758 & 1139213 & \multicolumn{2}{|r|}{1575311} \\
\hline $\begin{array}{l}\text { Community forest } \\
\text { group }\end{array}$ & $\begin{array}{c}\text { Total area } \\
(\%)\end{array}$ & Total HH (\%) & $\sum Y \mathbf{i}$ & $\sum X i(Y i+1)$ & $\sum(\mathrm{Xi}+1) \mathrm{Yi}$ \\
\hline less than 10 ha & 1.2 & 11.8 & 7.61 & 38.67938 & 27.80731 \\
\hline 10 to $50 \mathrm{ha}$ & 11.9 & 31.1 & 20.02 & 398.2228 & 245.1435 \\
\hline 50 to $100 \mathrm{ha}$ & 15.8 & 20.0 & 48.23 & 1793.808 & 1414.973 \\
\hline 100 to $200 \mathrm{ha}$ & 22.9 & 17.3 & 71.13 & 4065.084 & 3233.146 \\
\hline 200 to 500 ha & 28.2 & 14.8 & 86.92 & 7669.852 & 5645.273 \\
\hline 500 to $1000 \mathrm{ha}$ & 12.4 & 3.7 & 98.78 & 9877.699 & 8823.972 \\
\hline more than 1000 ha & 7.6 & 1.4 & 100.00 & 0 & 0 \\
\hline \multirow[t]{3}{*}{ Total } & 100.0 & 100.0 & & 23843.34 & 19390.31 \\
\hline & & & \multicolumn{3}{|c|}{$G=1 /(100)^{2}(23843.34-19390.31)$} \\
\hline & & & 0.44530 & & \\
\hline
\end{tabular}

